\title{
Investment Activity in Small Open Economies
}

\author{
Vera Karadjovaa,2, Snežana Dičevska' ${ }^{1,2}$ \\ ${ }^{1}$ Faculty of Tourism and Hospitality, Ohrid, Republic of Macedonia \\ 2University "St. Kliment Ohridski", Bitola, Republic of Macedonia \\ Email: verakaradzo@yahoo.com, sdicevska@yahoo.com
}

Received 20 February 2014; revised 20 March 2014; accepted 27 March 2014

Copyright (C) 2014 by authors and Scientific Research Publishing Inc.

This work is licensed under the Creative Commons Attribution International License (CC BY). http://creativecommons.org/licenses/by/4.0/

(c) (i) Open Access

\begin{abstract}
The paper gives a brief elaboration of the basic macroeconomic aspects of investments with emphasis on the specificities of small open economies in the process, theoretically elaborates the need for openness of small economies (especially the economies that need the acceleration of their development), then highlights the risks and opportunities arising from the investment activity both on the micro and macro level. Further distinguishes between investments in financial instruments and in real investment projects, emphasize the need for creation of an optimal diversified portfolio. Finally, the paper underlines the need for various forms of foreign direct investment for all economies, particularly the opportunities and threats arising in small open economies, to complete the wholeness with empirical data of the previously elaborated matters on the example of the Republic of Macedonia as a small open economy.
\end{abstract}

\section{Keywords}

Small Open Economy, Risks, Diversification, Foreign Direct Investments, Republic of Macedonia

\section{Introduction}

Investment activity is risky endeavor that requires a comprehensive analysis of the risks that occurs and analysis of the expected effects. Globalization and modern technology has accelerated the international flow of goods, services and capital, making investment activity more risky, and in the same time more accessible for small economies that do not generate enough savings. In this sense, small open economies are inevitably directed to the use of foreign accumulation and to the attraction of foreign investments in order to accelerate and intensify their development, with all challenges that arise from such a decision.

The decision to invest defined as the process that determines the current situation, formulates alternative solutions, selection one of the potential alternatives and implementation of the selected alternative becomes 
particularly complex in terms of increased uncertainty and risk, especially where such decisions are implemented by using foreign accumulation.

The investment decision is an inter time decision that bridges the gap among the postponed consumption and the future production and supply. In that sense, this decision is closely related to the distribution of the GDP by the purpose, but also with the rest of the world (international trade). Such activity observed integral on a level of national economy, is determined by a number of factors that make a close interactive relationship anyway, especially in small open economies.

Starting point when planning investment activity in each case is a standard formula for the expenditure principle of formation of GNP (Gross National Product), which expresses the distribution of GNP by the purposes earmarked for certain expenditures of the state, citizens, businesses and exports:

$$
\mathrm{GNP}=\mathrm{C}+\mathrm{I}+\mathrm{G}+\mathrm{X}-\mathrm{M} \text {, }
$$

where GNP denotes the gross national product, $\mathrm{C}$ denotes personal consumption, I-investments, G-government spending, $\mathrm{X}$ —exports (eXsport), and $\mathrm{M}$-imports (iMport) [1].

In terms of market-oriented economic system ${ }^{1}$ as now build up the largest number of countries, including most of the small open economies, the allocation by the purpose (expenditure principle of distribution) is a result of business entities autochthonous decisions, under real and consistent impact and application of market principles. Having this in mind, it becomes clear that when discussing the politics of distribution we are talking exactly about income distribution where income is intended for specific needs, whereas here the focus is on investments as a need. This distribution is accomplished autochthonous and completely independent but with relatively more or less direct or indirect influence of the state.

Specificities of small open economies are perceived in need of monitoring the international transfers of capital and interest rates on the world financial markets. Financial intermediaries that mediate between surplus and deficit sectors of the economy (domestic and foreign) allow free capital flow (despite tighter regulation of the financial sector), and it happens the economic phenomenon of interest rate parity ${ }^{2}$. This means that a financial line of integration as a graphic view of the said phenomenon is totally exogenous factor for small open economies and that determines their specific position regarding their investment activity. Future production function must take into consideration inter temporal budget constraints the economic subjects are faced with as well as expectations about future economic trends. In anticipation of future production function also must be taken into account the principle of declining marginal productivity. In this context it could be priced the decision to invest in any economy, with special emphasis on the specifics of a small open economy. Taking into account their usually inevitable direction to use someone else's capital, an additional aspect of expertise is the cost of investment (the aforementioned parity of interest rates) and the expenditure structure of investment (a part for production consumption and a part for final consumption retrospectively).

Small open economies with particular attention need to analyze the structure of investments in financial instruments and in real investment projects (which are directly related to job creation, supply, prices decline and other macroeconomic categories which in long-term balance the national economy to the state close to the macroeconomic balance), and also need to analyze investments efficiency to achieve that having in mind the opportunity costs arising from current sacrificing of a part of the income or from a debt. In this sense, small economies are almost as a rule referred to the need to include in their investment activity foreign direct investments, and the point of expertise which is necessary in this area is a form of the realized foreign direct investments with all advantages and disadvantages arising from the appropriate form.

\section{Why Is It Necessary Openness of the Small Economies?}

The previous economic history and economic theory unambiguously confirmed that no national economy can not survive in conditions of autarchic (closed) economy in which domestic consumption would be met exclusively with domestic production. On the contrary, there are many reasons and purposes for which a country establishes economic relations or links its national economy with the economies of other countries.

First of all, no country produces everything which is necessary to meet the needs of the economy and the population. With this in mind it can be said that the basic reason for the existence of economic relations among

\footnotetext{
${ }^{1}$ Macedonia in a socialistic socio-economic system had a planning oriented economic system.

${ }^{2}$ Aligning the rate of return on assets with similar quality characteristics (maturity, risk, etc.) under conditions of perfect efficiency of financial markets and the free capital flow.
} 
countries in the world stems primarily from the need to supplement the production structure of the country. This is particularly the case for small economies with limited scope or type of resources. Each country is guided by comparative advantages and alternative costs and is so determined and specializes to produce those products that have comparative advantages, lowest alternative costs, and which may be offered for sale on the world market.

Another basic reason for linking the country's economy with the economies of other countries in the world is the influence of foreign economic relations on the formation and distribution of gross domestic product. Thus, some countries achieve high production that they do not spend a whole inside the country (certainly on particular allocation system), but are able to lend a part of that production to other countries in the form of credit or otherwise. On the other hand there are countries, in particular least developed countries and developing countries that cannot meet the needs of the population and the economy using only its own production, and have inevitable need of foreign income to supplement domestic savings, which would be used for economic development. In such conditions the assumption which has to be included is that the borrowed foreign income be used for creation of economic conditions and manufacturing facilities that will be able to repay the borrowed funds. If borrowed funds are used irrationally, for example most of them for private and public consumption and a less part for investment spending, then it will create problems with the return of the external debt and reduce the possibilities of getting new loans for development.

Basic type of foreign economic relations is foreign trade relations, i.e. import and export of goods ${ }^{3}$. Given that no country can meet the growing needs only with its own production but must be linked to other countries, and have to import or export goods and services. Only in exceptional cases such as wars, economic crises and so on, a country can be brought into a state to satisfy domestic consumption only with its own production.

Each country as a rule is striving to finance alone its development using its own savings without having to borrow abroad. Undeveloped and less developed countries often do not have such economic independence because by its own production barely cover existential needs, and their saving a so small to achieve independent economic development. These countries need to use someone else's income, primarily for economic development. Developed countries from its side usually does have that kind of economic independence, i.e. they can with their own production and their own savings to provide consumption by volume, and can provide such a savings that can provide further economic development. However, in modern conditions of free flows on the international capital market developed countries also use someone else's income to provide even faster economic growth, and foreign capital finds its interest in safer and faster growth.

Specifically speaking many conditions can be indicated that determine the foreign economic relations of the country with other countries. The main reason and requirement for external economic relations between countries is limited natural resources, or in other words the diversity of natural resources the countries dispose with. Striving to expand, to diversify domestic production, to produce as many different products, some countries have to import raw materials and inputs that do not have and to export those raw materials that have in quantities that exceed domestic needs. Different natural conditions for agricultural products also affect the connectivity of the national economy of a country with other countries. Even small economies can have specific and unique resources that can be exported to the world market or to specialize in a certain type of production and thus to engage in the international division of labor [2].

In this context as a requirement and reason for the spread of external-economic relations among countries in the world is also the transfer of technical-technological progress that goes from developed to less developed countries, starting by imports of new advanced equipment, through the purchase of patents and licenses, until establishment of long-term production cooperation and joint ventures, where despite the additional capital in less developed countries comes a new technique, technology, new management and marketing, new markets, etc.

Foreign economic relations occur in various forms, such as import and export of goods, performance and using services, lending and borrowing, equity joint ventures, state's and population's financial transfers, transfer of technological development etc. However, the basic and most important form of foreign economic relations is foreign trade relations, i.e. imports and exports of goods. In this sense, the trade balance is most important sub balance, the most important and biggest item in the balance of payments and that the participation of imports and exports in GDP measured the degree of linkage of the national economy with other foreign sides.

\section{Risks and Opportunities of Investment Activity}

The investments are extremely risky activity. Investment activity is usually associated with the calculation of

\footnotetext{
$3+\mathrm{X}-\mathrm{M}$.
} 
rate of ROI which should be greater than the interest rate on alternative investments, but also greater than the interest rate on eventually borrowed funds regardless of the forms of borrowing. In this sense, investment activity is related to the proper form of a SWOT analysis, especially of the external environment (threats or risksand opportunities). Such analysis is necessary on a micro, and on a macro level, with special emphasis in small economies where have to be analyzed the essential macroeconomic variables and country risk as an integral indicator for the determined country. Important moments in Risk Management are the types of risks faced by business entities and the economy as a whole, while the most significant risks can be categorized according to different criteria. Despite the numerous categories of risks, their analysis is further complicated by interactions of the various risks.

However, the review of basic risk kinds is a necessary requirement for understanding of the reasons that cause them, and the consequences arise from them in direction to find methods and techniques for dealing with those consequences. The point is clearly to minimize losses and to maximize the use that may arise from managing certain risks.

As basic risks types in Table 1 can be emphasized [3]:

Risk as a probability or possibility of an unfavourable event exists in all areas of life and work and can manifest in several forms. Classified from different aspects for its easier determination and management, it can be observed as: individual and general risk according to the area it refers to i.e. has effect on; static and dynamic risks, the dynamic being a result of changes in the economy — changes in prices, in customer preferences, in income, in technology, in scope of production etc., while static risks appear without changes in the economy as a whole. Those risks find their source in various types of natural hazards or dishonest behavior of individuals or economic entities. One of the most useful risk divisions is to pure and speculative risks. Speculative risks refer to situations in which the probability of loss exists, together with the probability for profit, and with pure risks there is the possibility of making or evading the loss. This division is exceptionally important because usually there is a possibility to get insurance only against the pure risks. The analysis of non-financial and financial risks covers the term risk in the widest context and refers to all situations in which there is exposure to liabilities, i.e. the danger of financial loss, or in a case of non-financial risks-non-financial loss. The country risk is especially important area when analyzing risks and it imposes the need of special attention when planning the work of every business entity and formation of its product. This has especially significant place in the example of small developing economies and transition economies. Thus, one has to analyze the aspects or blocks of risk factors which contribute to a greater or lesser influx of investments into the country in general. Market risk as a sublimate of the interest risk and currency risk is a particular area of financial risks which all enterprises face more or

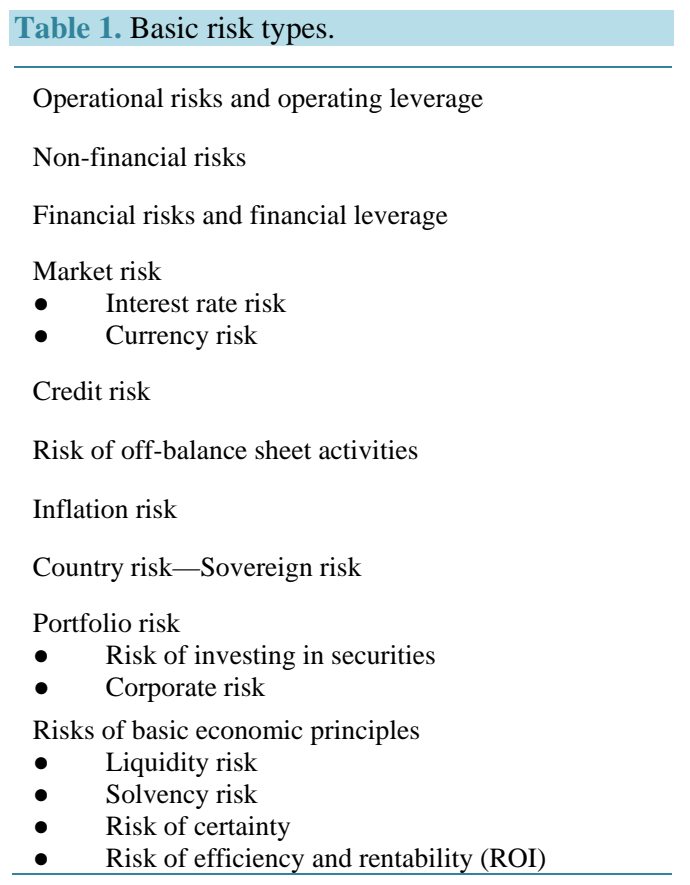


less. The inflation risk and its dependency on the measures of the state's macroeconomic policy i.e. holders of the economic policy is also in direct correlation with the work of every business entity. A different categorization of risks that needs to be taken into consideration during investing activities are risks of basic economic rules as a sum of principles, directions and criteria for effective and efficient work of the business entities, above all the principles of liquidity, solvency, security, efficiency and profitability. Portfolio risk of any enterprise should be considered as a sublimate of portfolio formation through investing into securities or through investing in real estate investment projects, where the so called corporative risk appears. Both cases are matter of forming a portfolio as a manner of risks diversification and decreasing the non-systematic i.e. specific risk, and the separation can be achieved only through the criteria of the types of assets in which one invests.

An important point in managing the risks is that they should be evaluated, i.e. quantitatively expressed. In the most important methods to measure different types of risk are:

- Risk metrics model for measuring market risk,

- ALM concept for measuring interest rate risk (through GAP analysis-reprising model), maturity model, duration model,

- Methods for measuring currency risk,

- Methods for measuring credit risk, default risk measurement, and problem of loans portfolio and risks concentration,

- Measuring the risks of off-balance sheet activities,

- Measuring operational Risks,

- Models for assessing country risk.

Measuring the risks of every kind is not a goal to itself, but the measured size is necessary to put in relation with the yield, i.e. to optimize the risk-return ratio. Therefore it is necessary first to calculate the rates of return and than to put them in relation to the potential risk. The possibility of failure of the expected yield which can vary in different forms of investment determines the size of the risk and for its measurement there are a number of mathematical, statistical measures and measurement procedures.

The most important among them are: range measuring; standard deviation; and coefficient of variance. A special point about risk measurement refers to the measurement of portfolio risk and calculating $\beta$ (beta) coefficient. Measuring the risk of the portfolio must be supplemented by the application of the principle of portfolio diversification using which the risk can be considered as systematic (non-diversificated) and unsystematic (diversificated) risk.

The Figure 1 shows the impact of the change in the number of securities in the portfolio on the risk of the whole portfolio.

There are a number of alternative rates, which can be used for calculation of the returns on investments, such as (total yield for the all time of investments in shares (HPR-Holding Period Return, APR-Annual Percentage Rate, EAR—Effective Annual Rate etc.), and the yield of the entire portfolio, as well as relationships of so calculated yields with the potential risks.

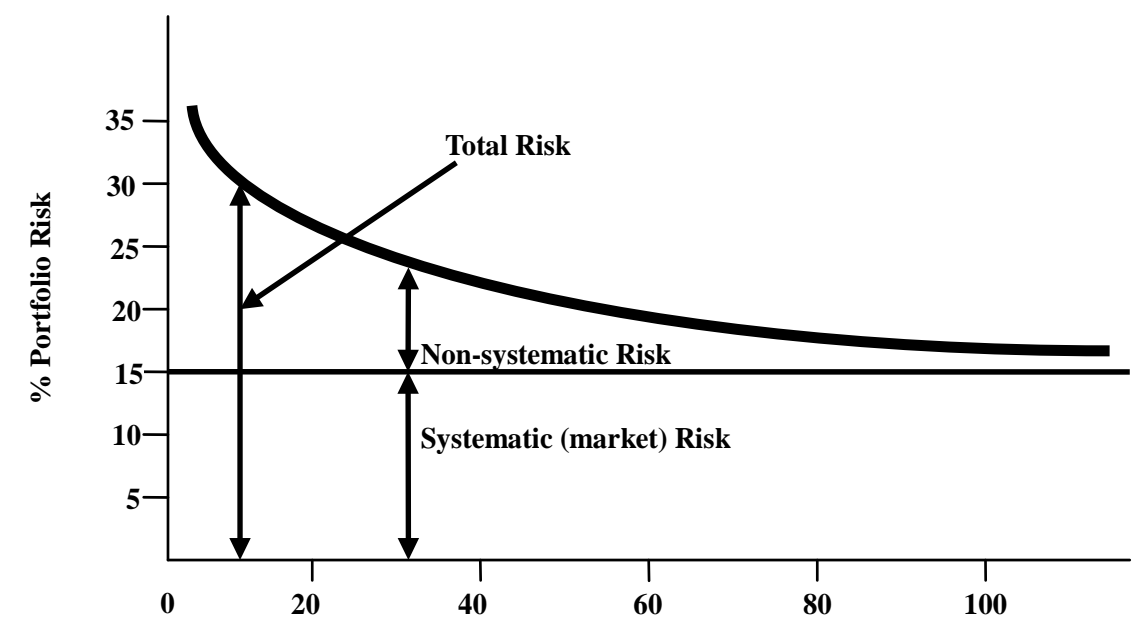

Figure 1. Portfolio diversification. 


\section{Financial Investments and Investments in Real Investment Projects}

Starting from the functional connectivity of the financial and real sector of the economy, no matter in which sector investments are realized, they are in anyway associated with economic growth and development.

There are so many issues determining the relation between financial and real sector. The first deals with the influence that financial conditions have on aggregate expenditure and overall economic developments. The second reverses the direction and looks at the impact of the macroeconomic environment on the financial health of different economic sectors. Third deals with the evolving nature of the measurement of financial risk both at the micro level of individual economic subjects and at the macro level of whole sectors or the economy. One aspect of the interaction between the real and financial sectors is the influence of financial conditions of firms and households on consumption and investment. On the demand side, production and consumption decisions are critically dependent on the underlying financial condition of economic agents. High levels of debt that are not supported by robust income flows can restrict the absorption capacity of the private sector and become a drag on economic expansion or even result in an economic slump. On the supply side, those same financial conditions are a key factor in determining the terms on which external funding is granted. Asset prices play a key role in the process, on both the demand and supply sides [4]. The interaction between prevailing financial conditions and real economic activity also runs in the opposite direction. The state of the business cycle has an important influence on incomes, profits and, by extension, the balance sheets and creditworthiness of various economic players. Understanding these links is no less important, especially if the objective is to gain insight into the feedback mechanisms that determine the overall impact of developments or policy actions on the state of the economy.

Investing in securities or formation of a portfolio of securities of the economic entities have realized for different purposes and tasks, among which mostly for liquidity management and management with the excess of free funds, for the realization of interest income or capital gains, etc. To determine an appropriate strategy for dealing with securities, allocation of funds and proper evaluation of the results of work with securities, the manager must previously quantify the objectives of the policy of the operations with securities.

In almost all developed financial systems and in the financial systems of small economies in transition institutional investors (insurance companies, pension funds, mutual funds, investment funds, investment banks, etc.) and other economic entities form portfolio of securities as a form of investment of the temporarily free funds. With this feature though they realize socio-economic goals, they realize individual goals too, in the sense of increasing their profitability. A substantial part of the assets that are temporarily free, can be placed on the financial markets and the marketing of such funds subjects tend to make a profit in at least the amount of the average interest rate earned on the capital market. The placement of funds is directed in three main directions [5]:

$>$ buying real estate or direct approval of mortgage and other loans;

$>$ buying securities; and

$>$ depositing cash in banks and other depository financial institutions.

The types of securities in which the funds can be invested in short or long term are different and have different risk and return for the investors, and the selection of those which will enter into the portfolio is determined by several elements. Finding the own needs and financial possibilities manager needs to decide for securities that will best meet the needs of the economic entity. In this regard, among numerous criteria that can be used can be specified:

- risk of payment of interest and principal (credit risk);

- interest rate risk (the risk of changes in market interest rates);

- risk of maintaining the purchasing power of the investment (inflation risk);

- liquidity risk, and

- returns that can be derived from the security.

In any case, investing in financial property must meet the rule for the formation of effective portfolio, i.e. each individual subject tends to optimal or the best possible portfolio in the certain circumstances, having regard to the right proportional relation between the categories risk and yield.

The Corporate risk of the economic entities can be treated as a subspecies of the former, i.e. risk of investing in securities if they invest in projects in other subjects or government projects through financial markets i.e. through the purchase of their securities. The basic points to which have be putted attention are period of maturity, liquidity and risk. Investors mostly prefer buying attractive securities (marketable securities) which allows them 
flexibility and leave space on hesitating which is very convenient on their investment performances.

Having in mind that this risk was already discussed, here the emphasis should be placed on the possibility of investing in real investment projects and the risks occur. Investment projects are invariably risky ventures and are such as a "victim" in the present for the effects for which there is a "hope" that will occur in the future. A future in turn is full of uncertainties and insecurities and imposes dilemma to the investor on acceptance or rejection of the projects under consideration as alternatives. Thereby introducing abstraction that in this respects it is irrelevant the way that investment is realized (through the financial markets or outside of them). Relationship that is considered here concerns the correlation risk-return and length of time in which they are expected, considering the generally accepted rule that investment $\$$ available at present is worth more than at any point in the future. The need to make the right decision in terms of investment of own funds or available funds provided by external sources in projects with lower risk and lower return or projects with higher risk and return, requires the need for identification and quantification of the risks that may arise. Therefore it is necessary to assess the effectiveness of the investment project for which purpose a whole methodology is developed within the investment management. The methodology includes economic_-financial analysis of the investment project, projecting of the flows of expected returns, calculation of expected liquidity, and calculation of criteria by which cost-effectiveness is measured, and adjustment of the estimates of risks that can be expected to occur. The use of numerous investment criteria for making the investment decision, investment criteria that are based on the concept of the time value of money (the period of return on investment, average rate of return on investment, etc.) and criteria based on the concept of time preference of money (net present value of the project, profitability index of the project, internal rate of profitability of the project, etc.) are conducive to investment decisions, but do not take account of the riskiness of the projects evaluated. In their application usually starts from the position that all projects are with equal risk or risk free which not fit the reality. Therefore, it is necessary to be used methods based on the above, but which must contain the settings of risk and its incorporation into the decision model. It is about of application of mathematical methods and models for business decisions that belong to the categories of models for decision making under conditions of risk and decision making under uncertainty. In this case, it cannot be discussed about the application of so-called deterministic models of decision making or models of decision making under conditions of certainty. Decision making under conditions of risk is characterized by the fact that the decision maker know only the probabilities for different alternatives. The models on the decision in terms of risk must include also the calculation of risk in solving a problem, so called stochastic models or simulation models. Models of decision making under uncertainty are models in which decision making takes place under conditions of uncertainty, because the decision maker has not the opportunity to determine the probability of occurrence of a certain event. These models mainly fall into the area of game theory [6].

Projecting the costs and revenues of the project normally is based on assumptions and predictions that must not be effected and that must be considered as probable and not certain. The number of factors that can derail the expected cash flow in uncertain future contains a wide range of elements and basically speaking the deviations of actual sizes are greater as longer is the projected operating period of the project and the bigger is the amount of investment. Ultimately, the failure of some large investment projects due to the abstraction of some of the risks can lead to illiquidity, insolvency or even bankruptcy of the economic subject. In particular we are talking here about so-called risks of business that can be considered as: risks of technical-technological progress, market risks and risks of changes in the structure of the cost. The analysis of such risks must include the factors that cause them where external factors reflect the impact of changes in system conditions and measures of economic policy and the investor can not influence them, but just need to diagnose them and adapt to them; and internal conditions that reflect the impact of changes in variables of the project. These variables are under the direct control of the investor, but in any case it is a need for a great skills and knowledge in order to manage them.

The risk of investment in real investment projects can be determined as a possibility the project not be able to meet the criteria on profitability, in a sense of for example that the net present value of the project is not greater than zero (NPV > 0), the internal rate of cash flows is not greater than the cost of capital (ISP > k) and as uncertainty of cash flows caused by some degree of their variability. About the projects for which we are speaking here, i.e. in projects where the investment is in real goods the risk most often comes from operating flows, which in turn depend on a number of variables that make implications for sales volume, sales prices, operating costs and similar to them. Despite this, initial investments have a great degree of certainty; they are made in the present and are with a degree of reliability. Therefore the concept of facing the risk of investing in real investment projects spanning multiple approaches on adaptation of the projects to the risk. Anyway, the starting point 
is the present value of the project, but not the net present value, but the present value of cash flow because investments are undisputable and certain. Because of that, the risk analysis refers to the expected net inflows in the future. Thus the inclusion of risk means to the projected net returns to be seen as the hope on expected returns, rather than as a certain amount. The application of the concept of probability of occurrence of the expected returns means they have to be seen as a product of the projected volumes of the net-returns and estimated probability to occur. The calculation of the value of expected returns is not the end of this procedure, but it involves determining the standard deviation on individual projects in order to conclude which project is less risky, particularly if there are projects that exclude each other.

\section{Foreign Direct Investments (FDI)—Opportunities and Constrains for Small Economies}

Foreign direct investments (FDI) are one of the forms for foreign capital inflow by which the investment activity of individual economies is intensifying, and which is essential for small economies. In fact, it is a long-term investment capital from the rest of the world. Foreign direct investment can manifest through various forms of international capital flows, but also are profitable for investors.

Direct investments from abroad may have one of the following basic forms:

- founding of a new economic entity or undertaking the existing one;

- merge with existing subject of domestic investor;

- founding a common entity with domestic investor.

Thus, foreign direct investments directed in a certain economy appear as:

1) Founding of a new economic entity (Greenfield investments) when foreign investor build new manufacturing capacity and holds $100 \%$ ownership by himself;

2) The acquisition of a majority share in the ownership of an existing economic entity by purchasing of a company, buying shares or direct purchase of the ownership stake-merger \& acquisition;

3) Joint venture with the entities from the host country (recipient of the foreign investment)—joint venture.

The split of the foreign direct investments can be made in other ways, however it is important to know that every company has different reasons when making the decision where and how to invest. Whether a company decides to invest in a country depends on many factors, especially on the assessment of profits that can be achieved, the maturity of the operation, and the willingness of the host to accept, accelerate and facilitate the operation [7].

The form in which FDI occur the most is conditioned by the frame determined by the legal order of the state in which the investments are make, but also by the investment strategies of the foreign investors. Foreign direct investments are not solely financial investments, but it is a package of capital in various forms, know-how and managerial knowledge. Such investments may include equity in the form of land, buildings, machinery, finance assets, new technologies and management knowledge.

\subsection{Advantages and Disadvantages of Foreign Direct Investments for Small Open Economies}

The positive effects of FDI on small open economies are reflected in the transfer of technology and knowledge; tend to increase their participation in world trade, increase in foreign exchange inflows, deficit reduction, job creation, or economic growth and economic development. For a large number of small economies foreign direct investments are an important element for activation of their potentials, better use of available resources and access to cutting-edge technology. The use of foreign investments provides an investment beyond the capacity of domestic savings, without increasing the level of indebtedness. Through FDI country provides the needed capital, advanced technology, new management practices, and has access to international markets for export of the products, increases competition among economic entities, increases productivity, creates a modern management system and promotes educational and practical knowledge of the human resources.

The direct foreign investments provide the following benefits for the host country:

* Entry of new, modern technologies;

* Rational utilization of domestic resources;

* Developing of new industrial sectors and branches in a relatively short period of time;

* Increasing the competition between existing entities in a separate sector which initiates raising quality and 
lower prices;

* Increasing the employment;

* Increasing the exports and foreign exchange inflow;

* Reduction of indebtedness abroad on a long-term.

Besides the possibility of creating new jobs and increasing the employment (small economies and developing countries generally have relatively bigger or smaller problem with unemployment), foreign direct investments in a same time enable the growth in wages and thereby improve the living standards of the population and increase demand in an economy.

Despite frequent policies of tax reductions and exemptions for foreign direct investments in the first years of operation in order to attract more FDI, they also generate positive fiscal effect in the host country in the next years.

Among the numerous positive effects of foreign direct investments on the economy of the host country, also can be specified certain weaknesses or negative impacts on small economies.

Eventual negative repercussions caused by foreign direct investments in the host country or for the investor:

$>$ External control and management;

$>$ Unfair competition with existing facilities (foreign companies often are more powerful, more competitive, more modern and have a capability to use economies of scale more easier);

$>$ Excessive exploitation of natural resources by powerful investors;

$>$ The emergence of social and cultural distortions;

$>$ Increased costs for travel and communication because of the spatial distance from the headquarters;

$>$ There is a possibility of occurrence of adverse effects and risks for the economic entity that invests in terms of political, legal, social, security and economic instability in the host country; complex administrative procedures for regulation of the property relations; insecurity; difficult access to information etc.

\subsection{Case of Macedonia}

After the independence of the Republic of Macedonia in 1991, the country built a new social economic system based on market principles. Basic social-economic relations defined by the Constitution inter alia are relating to [2]:

$\checkmark$ Legal protection of property, the right to property and inheritance and equality of all types of property;

$\checkmark$ Free market relations and entrepreneurship, equal legal status of all market subjects and taking measures to prevent monopolistic position on the market;

$\checkmark$ The right to work, free choice of employment, occupational safety and material assistance during temporary unemployment, the right to social security, health care, healthy environment, etc.;

$\checkmark$ The rights of foreign investors and the independence of the National Bank.

In that sense the country have accomplished an economic transition in which the elements of the new system that changed the country's economic structure can be classified into four main groups of categories that are linked to each other in an integrated process including: 1) macroeconomic stabilization and control; 2) pricing and market reform; 3) private sector development, privatization and companies restructuring; and 4) redefining the role of the state. Referring to those changes, the main feature of the current economic system that makes it quite different from the former represents recognition of all forms of property in circumstances where any form of ownership is not privileged. Another essential feature of the economic system of the Republic of Macedonia is a consistent application of market principles and mechanisms and the existence of an integral market (market of goods and services, money and the capital market, and labor market). So these characteristics and other naturally derived from them created conditions for stimulating the free flow of capital and attracting foreign investments. The existing legal regulation was amended and was designed to provide equal rights and conditions for domestic and foreign investors and in direction of protecting their rights through greater security of foreign investments, everything in order to increase the attractiveness of the country [8].

In current conditions, in December 2011 a Programme for Stimulating Investment in the Republic of Macedonia for the period 2011 to 2014 was made, with the primary aim of developing policies and implementing reforms that will lead to more dynamic economic growth and development, by improving the general business climate and increasing investments. In addition, intentions on a national, regional and local level are aimed 
at improving the investment climate and building strong institutional basis for attracting domestic and foreign investments in order to achieve sustainable development of the country. In Macedonia there is an Agency for Foreign Investments and Export Promotion of the Republic of Macedonia ${ }^{4}$, which is one of the most important institutions for potential investors (primarily for Greenfield investors) or those who show an interest in investing in industrial and technological development zones. Technological and Industrial Development Zones offer a range of benefits to potential investors, including:

- Timing determined tax exemptions;

- Opportunity for long-term lease of land;

- Communal fees exemptions, i.e. connection for natural gas, water and sewer;

- Support in the registration process;

- Government subsidies.

Guided by the basic motive to maximize profits, and taking into consideration the safety of the investment, foreign investors choose a location that will allow the most profit with the least risk. It is in this context are the intentions of the Republic of Macedonia to improve the country's investment climate for attraction of direct investment from abroad. Macedonia is a small country with limited domestic sources for investments and the medium level of development, therefore, is directed to the use of foreign sources of investments.

fied:

As comparative advantages in attracting foreign investors in the Republic of Macedonia can be speci-

- Cheaper labor compared to developed countries and the countries in European Union;

- Solid level of educated professionals in many sectors of the economy;

- Favorable position on the Balkan Peninsula;

- Tax exemptions and incentives for foreign investments;

- A number of free trade agreements;

- Stabilization and Association Agreement with EU;

- Diversity of natural resources;

- Establishment of free trade zones (Free customs zones).

Nevertheless Macedonia as a small and underdeveloped economy in efforts to attract foreign investments must take into consideration the weaknesses i.e. limiting factors for attracting foreign investors in the country.

Basic weaknesses or limiting factors for attracting foreign investors in the Republic of Macedonia:

o Macedonia is a small country (25,713 square kilometers) with a small market (population of about 2 million people);

o Relatively low purchasing power;

o It is located in a relatively turbulent political security region (the Balkans);

o Macedonia is continental country, in landlocked;

o Inherited no confidence of foreign investors in some of the institutions and administrative procedures;

o Lack of developed technological base for certain industries;

o Versatile, but not much abundant natural resources;

o Need for further development of the infrastructure;

o The need for upgrading the financial system having in mind its predominantly Bank-centric structure.

Republic of Macedonia has made continuous efforts to attract foreign capital through the form of foreign direct investments. In this regard, a number of measures are undertaken and macroeconomic policies are carried, numerous reforms are implemented, including reform of the tax system, protection of property rights, improvement the efficiency in the functioning of the legislative, executive and judicial authorities and increasing administrative efficiency. However, further efforts are needed to achieve the desired level of foreign direct investments. The policy of the country for intensive attracting of the foreign direct investments is supported with multiple marketing campaigns (Invest in Macedonia, Macedonia Timeless) that represent the country through a worldwide electronic and print media. The following Figure 2 presents the situation of direct foreign investments and portfolio investments in Macedonia on 31.12.2012, according to the official data of the National Bank of the Republic of Macedonia.

The following Table 2 and Figure 3 present an overview of direct foreign investments in the Republic of

\footnotetext{
${ }^{4}$ The Agency was formed in 2004. Invest Macedonia is the official government agency responsible for attracting and developing foreign investments and export promotion. It is a full service agency prepared to guide throughout the decision-making process. As an institution dedicated to making this process as beneficial and effortless as possible, the Agency has various specialized departments.
} 


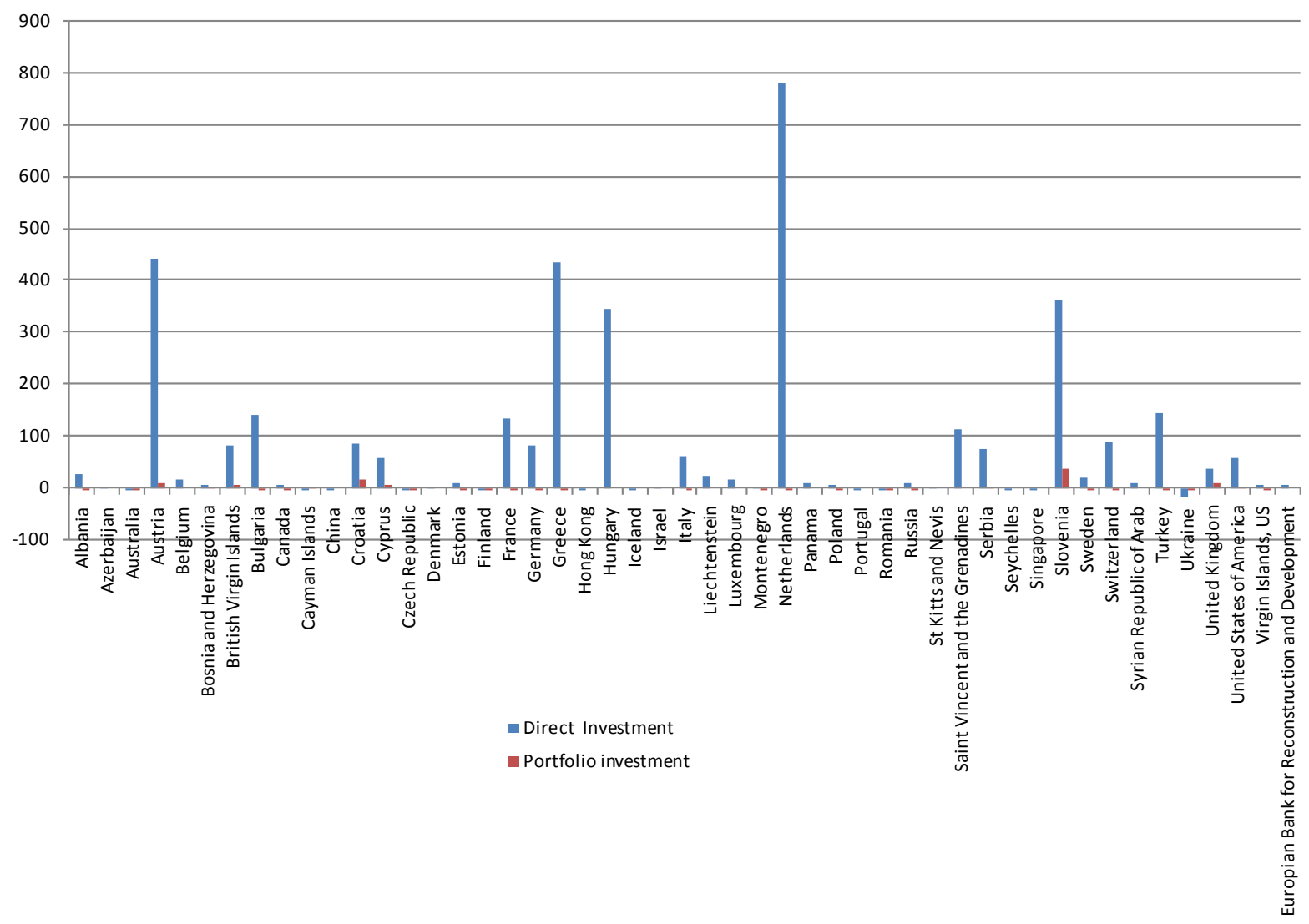

Figure 2. Stock of direct investment in Republic of Macedonia — by country, December 31, 2012. Source: according to National Bank of the Republic of Macedonia [9] [10] http://www.nbrm.mk/?ItemID=132C0210574E1A46A3B53952FD9FF05D [16.02.2014].

Macedonia by countries that invested through time series for the period from 1997 to 2012 year. It is noticeable the largest entry of capital from Austria, Greece, Hungary, The Netherlands and Slovenia, as well as some interruptions in the series.

\section{Conclusions}

The dynamics of the development of each national economy is associated with the volume and velocity of investments. The specifics of small open economies with respect to postulate of capital accumulation refer to their compulsory direction towards foreign accumulation in order to intensify development process. In this process they must have regard to monitoring the international transfers of capital and interest rates on the world financial markets.

Investment activity is basically determined by the allocation of GDP on a part for consumption (C) and a part for savings (S). The reduction in domestic savings followed by a simultaneous increase in investments generates a negative extension of the current account gap. Decline in real interest rates, easing of lending conditions and expansionary fiscal policy are major determinants of consumption growth at the expense of savings. This causes the need to finance investment activity through usage of foreign accumulation.

Capital flows cyclically accelerate or decelerate depending on the overall constellation in the global economy, and crisis and recession disorders are a basic condition for slowing the capital flow. This point must be taken into account by the small open economies because they cannot remain isolated of the events on the world economic stage. Such conditions impose the need to establish appropriate policies for access to foreign funding. External debt is one of the forms to supplement the shortage of accumulation, but it is a form that can easily cause an imbalance of the economy in the long run or sacrifice future consumption to recover debts. On the other hand, in conditions of the lack of liquidity, borrowing can be realized only by extremely high price. Therefore 
Table 2. Stock of direct investment in Republic of Macedonia—by country—1997-2012 preliminary date in million DEN.

\begin{tabular}{|c|c|c|c|c|c|c|c|}
\hline \multirow{2}{*}{ Country/Areas } & 2002 & 2004 & 2006 & 2008 & $2010^{1)}$ & $2011^{1)}$ & 2012 \\
\hline & Value & Value & Value & Value & Value & Value & Value \\
\hline Albania & 126.07 & 270.83 & 709.66 & 1467.75 & 2295.14 & 2243.02 & 1723.29 \\
\hline Australia & 110.89 & 128.61 & 141.75 & 147.19 & 148.77 & 125.09 & 127.23 \\
\hline Austria & 2301.99 & 3818.71 & 13422.34 & 20547.19 & 22861.52 & 25633.03 & 27159.90 \\
\hline Belgium & 30.72 & 80.16 & 54.23 & 72.12 & 72.05 & 118.85 & 1036.90 \\
\hline Bosnia and Herzegovina & 147.84 & 43.10 & 61.41 & 111.53 & 208.56 & 277.36 & 347.22 \\
\hline British Virgin Islands & 427.53 & 534.91 & 969.53 & 3151.01 & 4131.12 & 5801.78 & 5027.93 \\
\hline Bulgaria & 713.48 & 1491.57 & 2617.78 & 5312.23 & 7215.92 & 7398.28 & 8781.79 \\
\hline Belarus & & 0.46 & & & & & \\
\hline Canada & 5.80 & 25.25 & 65.07 & 193.81 & 254.31 & 238.56 & 409.90 \\
\hline China & 3.91 & 57.23 & 86.44 & 79.81 & 61.84 & 80.61 & 82.91 \\
\hline Taiwan & 212.63 & 156.18 & 132.25 & 47.02 & & & \\
\hline Croatia & 752.77 & 965.15 & 1871.60 & 3268.76 & 4435.34 & 4770.43 & 5254.91 \\
\hline Cyprus & 8646.65 & 9228.77 & 11147.57 & 2143.11 & 2841.89 & 2999.29 & 3546.48 \\
\hline Czech Republic & 10.94 & 15.86 & 17.62 & 30.11 & 155.07 & 42.01 & 113.34 \\
\hline Denmark & 5.96 & 4.07 & 32.74 & 78.05 & 111.51 & 163.47 & 282.36 \\
\hline Estonia & & & & 0.48 & 0.51 & 501.12 & 742.48 \\
\hline France & 656.40 & 1200.63 & 17.82 & 800.62 & 7965.15 & 8088.36 & 8290.62 \\
\hline Germany & 3204.44 & 4326.44 & 3920.30 & 4067.28 & 4393.77 & 5340.17 & 5162.15 \\
\hline Greece & 13009.18 & 16192.26 & 19599.98 & 27678.24 & 26518.04 & 27242.35 & 26827.35 \\
\hline Hong Kong & & & & 2.59 & 2.60 & -19.84 & 114.12 \\
\hline Hungary & 18327.38 & 21728.28 & 21432.42 & 25213.16 & 21333.08 & 21315.67 & 21305.46 \\
\hline Iceland & & & & 746.45 & 200.57 & 147.68 & 67.13 \\
\hline Israel & & & 0.62 & 252.69 & 269.99 & 90.72 & 144.05 \\
\hline Italy & 1007.67 & 1967.74 & 2715.32 & 3411.14 & 3601.04 & 4007.85 & 3857.55 \\
\hline Liechtenstein & 248.42 & 90.53 & 409.75 & 126.17 & 1094.35 & 1391.88 & 1497.11 \\
\hline Luxembourg & 140.49 & 663.88 & 1555.34 & 4246.08 & 991.20 & 948.28 & 1158.96 \\
\hline Montenegro & & & & 14.62 & 171.37 & 181.12 & 130.73 \\
\hline Netherlands & 3728.83 & 6329.09 & 12968.10 & 26749.39 & 33854.19 & 45537.38 & 48154.68 \\
\hline Panama & 812.47 & 182.73 & 252.62 & 683.20 & 754.80 & 641.80 & 617.32 \\
\hline Poland & 1.45 & 3.70 & 32.37 & 30.48 & 24.56 & 570.61 & 424.31 \\
\hline Portugal & & & 110.77 & 139.92 & 94.64 & 86.85 & 86.85 \\
\hline Romania & 20.08 & 28.98 & 3.35 & -15.69 & 114.85 & 110.09 & 84.28 \\
\hline Russia & 78.99 & 84.86 & 82.28 & 81.01 & 272.88 & 690.95 & 706.24 \\
\hline St Kitts and Nevis & & & & 180.26 & 179.47 & 160.39 & 159.65 \\
\hline Saint Vincent and the Grenadines & & & 1073.69 & 3816.20 & 5817.70 & 8558.80 & 6940.71 \\
\hline San Marino & 47.95 & 42.63 & 53.99 & 147.14 & & & \\
\hline Serbia & & & & 3826.33 & 4940.53 & 4361.78 & 4776.92 \\
\hline Slovenia & 4055.41 & 6244.26 & 7751.50 & 16137.86 & 24522.06 & 24949.89 & 22339.63 \\
\hline Spain & 1.36 & -2.56 & 1.41 & -8.23 & 10.65 & -5.07 & 29.67 \\
\hline Sweden & 143.18 & 153.79 & 157.13 & -108.11 & 317.06 & 1437.75 & 1289.84 \\
\hline Switzerland & 5200.22 & 8822.56 & 9223.91 & 12327.53 & 9411.27 & 7774.17 & 5510.18 \\
\hline Turkey & 1098.25 & 1624.02 & 1695.91 & 2639.26 & 2970.05 & 7210.10 & 8937.17 \\
\hline Ukraine & 0.55 & 39.35 & 200.60 & 54.40 & -863.11 & -1159.35 & -1065.99 \\
\hline United Kingdom & 778.42 & 1695.97 & 3263.97 & 7052.17 & 6306.51 & 2956.61 & 2397.32 \\
\hline United States of America & 2520.25 & 1570.53 & 2772.29 & 2935.19 & 2302.27 & 2631.32 & 3661.97 \\
\hline Virgin Islands of the USA & 13.53 & 50.88 & 76.16 & 429.27 & 347.68 & 334.56 & 434.43 \\
\hline Serbia and Montenegro & 1629.38 & 1808.45 & 3289.30 & & & & \\
\hline International Finance Corporation & & & & & & & \\
\hline $\begin{array}{l}\text { Europian Bank for Reconstruction } \\
\text { and Development }\end{array}$ & 561.46 & 807.69 & 943.79 & 1889.30 & 1286.75 & 1050.97 & 462.73 \\
\hline $\begin{array}{l}\text { Central African Countries } \\
\text { development support bank }\end{array}$ & & & 0.50 & & & & \\
\hline Northatlantic cooperation aliance & & & 57.68 & & & & \\
\hline TOTAL & 70885.21 & 98722.66 & 128378.29 & 182317.51 & 204339.05 & 227261.30 & 230404.82 \\
\hline
\end{tabular}

Source: National Bank of the Republic of Macedonia, [9] [10] http://www.nbrm.mk/?ItemID=132C0210574E1A46A3B53952FD9FF05D. 1) In September 2013 due to better data coverage, a revision of the data for 2010 and 2011 was done. 


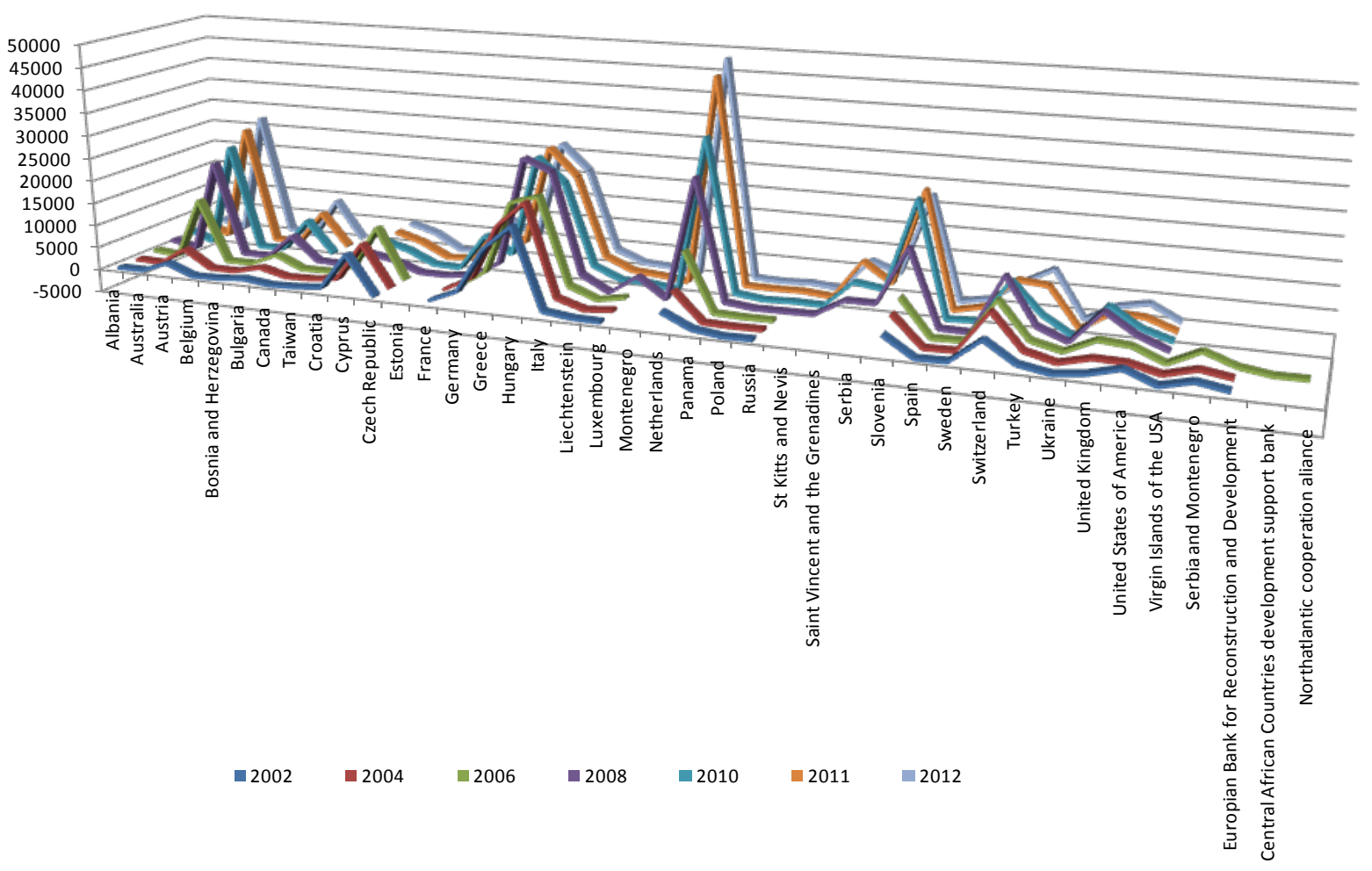

Figure 3. Stock of direct investment in Republic of Macedonia-by country, December 31, 2012. Source: according to: National Bank of the Republic of Macedonia [9] [10] http://www.nbrm.mk/?ItemID=132C0210574E1A46A3B53952FD9FF05D [16.02.2014].

the measures of macroeconomic policy should focus on increasing domestic accumulation, i.e. to increase domestic savings in order to ensure the maintenance of investment activities, or to some other forms of attracting foreign capital, which does not increase the indebtedness of the country. One of the potentially possible solutions in this sense is foreign direct investments.

Foreign direct investments (FDI) are one of the forms for foreign capital inflow by which the investment activity of individual economies is intensifying, and which is essential for small economies. In fact, it is a longterm investment capital from the rest of the world. Foreign direct investment can manifest through various forms of international capital flows, but also are profitable for investors.

The form in which FDI occur the most is conditioned by the frame determined by the legal order of the state in which the investments are made, but also by the investment strategies of the foreign investors.

The positive effects of FDI on small open economies are reflected in the transfer of technology and knowledge; tend to increase their participation of the small open economies in world trade, increase their foreign exchange inflows, reduction of their deficit, creation of new jobs. All that provides acceleration of the economic growth and economic development. The use of foreign investments provides an investment beyond the capacity of domestic savings, without increasing the level of indebtedness.

\section{References}

[1] Burda, M. and Wyplosz, C. (2001) Macroeconomics—European Text. Ina Komerc, Skopje, 44.

[2] Mojsoski, V. and Karadjova, V. (2002) Applied Economy, Economic System and Economic Policy. CNIR FTU, Ohrid, 365, 108.

[3] Karadjova, V. (2012) Principles of Risk Management, CNIR FTU, Ohrid, 99.

[4] Tsatsaroni, K. (2005) Investigating the Relationship between the Financial and Real Economy, BIS Papers No 22, 2.

[5] Kocovic, J. and Sulejic, P. (2002) Insurance, Economic Faculty, Belgrade, 200.

[6] Brajdić, I., (2006) Mathematical Models and Methods for Business Decision Making. Faculty for Tourism and Hotel 
Management, Opatia, 8.

[7] Dimitrijevic, M. (2000) Foreign Direct Investments, SIEPA, Belgrade, 12.

[8] http://www.investinmacedonia.com

[9] http://www.nbrm.mk/?ItemID=132C0210574E1A46A3B53952FD9FF05D

[10] http://www.stat.gov.mk 